\title{
PENGARUH KUALITAS PELAYANAN DAN LOKASI TERHADAP KEPUTUSAN PEMBELIAN PADA JOHAR FUTSAL KARAWANG
}

\author{
Robby Fauji ${ }^{1}$, Syifa Pramudita Faddila ${ }^{2}$ \\ robby.fauji@ubpkarawang.ac.id \\ Syifa.pramudita@ubpkarawang.ac.id \\ Program Studi Manajemen Fakultas Ekonomi Dan Bisnis Universitas Buana \\ Perjuangan Karawang \\ Jl. HS. Ronggo Waluyo, Puseurjaya, Telukjambe Timur, Kabupaten Karawang, \\ Jawa Barat 41361
}

\begin{abstract}
ABSTRAK
Sektor jasa mengalami pertumbuhan tinggi selama beberapa tahun terakhir, ratarata pertumbuhan sektor jasa selama delapan tahun terakhir mencapai 7,05\% per tahun. Salah satu sektor jasa yang cukup berkembang adalah sektor jasa di bidang jasa penyewaan lapangan futsal. Perkembangan bisnis jasa lapangan di Kabupaten Karawang mengalami peningkatan yang cukup signifikan setiap tahunnya. Jika pada era tahun 20092010 hanya ada beberapa bisnis jasa lapangan futsal yang ada di Kabupaten Karawang. Pada tahun 2019 kini sudah ada sekitar 45 bisnis jasa lapangan futsal yang tersebar di berbagai daerah di Kabupaten Karawang, salah satunya adalah Johar Futsal. Johar Futsal terletak di Jl. Veteran No 28, Kelurahan adiarsa timur, Kecamatan Karawang Timur, Kabupaten Karawang. Johar Futsal didirikan sejak tahun 2012 dan kini telah memiliki 3 Lapangan futsal untuk disewakan secara umum. Penelitian ini bertujuan untuk mengetahui dan menjelaskan pengaruh kualitas pelayanan dan lokasi terhadap keputusan pembelian pada johar futsal karawang, penelitian ini ini menggunakan metode deskriptif kuantitatif Variabel diukur menggunakan instrumen kuesioner dan skala pengukuran yang digunakan adalah skala Likert. Sampel dikumpulkan dengan menggunakan metode Sampling accidental dengan jumlah sampel 98 responden dari populasi 5.114 orang. Teknik analisis data yang digunakan yaitu teknik Analisis Regresi Berganda. Penelitian ini ditekankan agar memperoleh luaran yang akan di terbitkan di jurnal nasional terakreditasi dengan waktu capaian 6 bulan kedepan. Skema penelitian termasuk penelitian dasar (TKT 1-3).

. Teknik analisis data yang digunakan yaitu teknik Analisis Rentang Skala dan Analisis Regresi Berganda dengan bantuan Method of Successive Interval (MSI). Dari hasil analisis penelitian ini diperoleh beberapa kesimpulan yaitu

1. Hubungan antara Kualitas Pelayanan dan Lokasi dengan keputusan pembelian memiliki tingkat hubungan yang sedang.

2. Terdapat pengaruh parsial Kualitas Pelayanan dan Lokasi terhadap keputusan pembelian.

3. Terdapat pengaruh simultan antara Kualitas Pelayanan dan Lokasi terhadap Keputusan Pembelian.

4. Total Pengaruh Kualitas Pelayanan dan Lokasi memiliki kontribusi terhadap Keputusan Pembelian sebesar 31,6\% sedangkan sisanya 68,4\% merupakan kontribusi variabel lain $(\varepsilon)$ yang tidak diteliti.

Kata kunci : Kualitas Pelayanan, Lokasi, Keputusan Pembelian
\end{abstract}




\begin{abstract}
The service sector has experienced high growth in recent years, the average growth of the service sector over the past eight years has reached $7.05 \%$ per year. One service sector that is quite developed is the service sector in the futsal field rental services. The development of field service business in Karawang Regency has increased significantly every year. If in the era of 2009-2010 there were only a few futsal field service businesses in Karawang Regency. In 2019 there are now around 45 futsal field service businesses spread across various regions in Karawang Regency, one of which is Johar Futsal. Johar Futsal is located on Jl. Veteran No 28, Kelurahan adiarsa timur, East Karawang District, Karawang Regency. Johar Futsal was founded in 2012 and now has 3 futsal fields for rent in general. This study aims to determine and explain the effect of service quality and location on purchasing decisions in Karawang futsal johar, this study uses quantitative descriptive methods. Variables are measured using a questionnaire instrument and the measurement scale used is a Likert scale. Samples were collected using accidental sampling method with a sample size of 98 respondents from a population of 5,114 people. The data analysis technique used is multiple regression analysis techniques. This research is emphasized to get results to be published in accredited national journals with a period of 6 months. The research scheme covers basic research (TKT 1-3).

Data analysis techniques used are Scale Range Analysis and Multiple Regression Analysis techniques with the help of the Method of Successive Interval (MSI). From the results of the analysis of this study we obtained several conclusions, namely :

1. The relationship between Service Quality and Location and purchasing decisions has a moderate level of relationship.

2. There is a partial effect of Service Quality and Location on purchasing decisions.

3. There is a simultaneous effect between Service Quality and Location on Purchasing Decisions.

4. The Total Effect of Service Quality and Location has a contribution to the Purchasing Decision of $31.6 \%$ while the remaining $68.4 \%$ is contributed by other variables $(\varepsilon)$ which are not examined.

Keywords: Service Quality, Location, Purchase Decision.
\end{abstract}




\section{Latar Belakang}

Dunia bisnis yang tumbuh dengan pesat menjadi tantangan maupun ancaman bagi para pelaku usaha agar dapat memenangkan persaingan dan mempertahankan kelangsungan hidup perusahaannya, tidak terkecuali pada jaman sekarang dimana telah mengalami perkembangan dalam dunia usaha yang sangat pesat. Kebutuhan hidup masyarakat baik dilihat dari segi kebutuhan primer, sekunder, maupun tersier merupakan suatu kebutuhan yang ingin dipenuhi, terpuaskan dan tercapai oleh manusia. Kegiatan pemasaran memiliki peran yang sangat penting dalam dunia usaha, mengingat orientasinya terhadap masyarakat (konsumen). Keadaaan dunia usaha berubah dinamis seiring dengan perubahan selera konsumen dan perubahan yang terjadi pada lingkungan sekitarnya. Kebutuhan konsumen yang terus meningkat, menjadi peluang bisnis. Hal tersebut menjadi dasar pemikiran para pelaku usaha untuk memenuhi kebutuhan, keinginan, dan harapan konsumen sehingga tidak berpaling ke pesaing meski terjadi perubahan.

Keputusan pembelian konsumen merupakan salah satu bagian dari konsumen (consumen behavior) yang tercipta. Keputusan pembelian adalah tindakan dari konsumen untuk membeli produk baik itu berupa jasa ataupun berupa barang. Menurut Kotler dan Amstrong (2014:158) "Customer buyer behavior refers to the buying behavior of final consumers-individuals and households that buy goods and services for personal consumption". Keputusan pembelian menjadi suatu hal yang penting untuk diperhatikan karena hal ini tentu akan menjadi suatu pertimbangan bagaimana suatu strategi pemasaran yang akan dilakukan oleh perusahaan berikutnya. Perusahaan dalam memasarkan barang/jasa sangat tergantung dan harus benar-benar memperhatikan kualitas pelayanan yang akan diberikan dan penentuan lokasi dari perusahaan kita berjalan efektif atau tidak kepada pelanggan karena hal itu merupakan bagian yang penting untuk mempengaruhi keputusan pembelian konsumen. Menurut Kotler dan Keller (2012: 131), mendefinisikan kualitas pelayanan adalah kemampuan perusahaan untuk memuaskan kebutuhan dan keinginan konsumen. Jika kualitas pelayanan yang diberikan kepada konsumen sesuai dengan harapan konsumen, maka kualitas 
pelayanan mampu mempengaruhi keputusan pembelian konsumen dengan baik, tetapi jika kualitas pelayanan yang diberikan kepada konsumen tidak sesuai dengan apa yang diharapkan oleh konsumen maka kualitas pelayanan tidak akan mampu mempengaruhi keputusan pembelian konsumen dan keputusan pembeliannya cenderung lambat.

Faktor Lokasi merupakan salah satu faktor krusial yang berpengaruh terhadap kesuksesan suatu jasa, karena lokasi erat kaitannya dengan pasar potensial penyedia jasa untuk memperpengaruhi keputusan pembelian yang akan diambil konsumen untuk membeli suatu produk. Menurut Tjiptono (2015:345) Lokasi mengacu pada berbagai aktivitas pemasaran yang berusaha memperlancar dan mempermudah penyampaian atau penyaluran barang dan jasa dari produsen kepada konsumen. Lokasi yang mudah dijangkau oleh konsumen dan dekat dengan pusat keramaian merupakan lokasi yang tepat untuk suatu usaha, termasuk usaha di bidang jasa lapanagan futsal. Sebelum seseorang atau sekelompok orang memutuskan untuk menggunakan jasa lapangan futsal, mereka akan mempertimbangkan lokasi terlebih dahulu.

Perkembangan bisnis jasa lapangan di Kabupaten Karawang mengalami peningkatan yang cukup signifikan setiap tahunnya . Jika pada era tahun 20092010 hanya ada beberapa bisnis jasa lapangan futsal yang ada di Kabupaten Karawang. Pada tahun 2019 kini sudah ada sekitar 45 bisnis jasa lapangan futsal yang tersebar di berbagai daerah di Kabupaten Karawang, salah satunya adalah Johar Futsal. Johar Futsal terletak di Jl. Veteran No 28, Kelurahan adiarsa timur, Kecamatan Karawang Timur, Kabupaten Karawang. Johar Futsal didirikan sejak tahun 2012 dan kini telah memiliki 3 Lapangan futsal untuk disewakan secara umum. 
Tabel 1.1

\section{Daftar Bisnis Jasa Lapangan Futsal di Karawang}

\begin{tabular}{|l|l|}
\hline Alamat & Nama \\
\hline $\begin{array}{l}\text { Jl Veteran No 28, } \\
\text { Adiarsa Timur }\end{array}$ & Johar Futsal \\
\hline $\begin{array}{l}\text { Jl. Jend A.Yani, } \\
\text { Nagasari }\end{array}$ & Centro Futsal \\
\hline $\begin{array}{l}\text { Jl. Surotokunto, } \\
\text { Adiarsa Timur, }\end{array}$ & Ganesha Arena \\
\hline & Dan lain-lain \\
\hline
\end{tabular}

Sumber : Peneliti (2019)

Dari beberapa bisnis jasa lapangan futsal diatas. Peneliti hanya melakukan penelitian pada Johar Futsal Karwang. Beberapa bulan terakhir ini mendapatkan sedikit masalah tentang jumlah pendapatan pada tahun 2018 yang mengalami penurunan cukup signifikan dalam 2 bulan teakhir. Hal ini jelas akan membuat usaha yang dijalankan akan mengalami penurunan pendapatan yang kemudian akan menjadi kerugian tersendiri bagi pihak perusahaan. Keputusan pembelian konsumen bisa menjadi salah satu masalah bagi bisnis jasa ini karena berdasarkan dari hasil observasi awal yang dilakukan terdapat beberapa permasalahan tentang kualitas pelayanan dan lokasi di Johar Futsal, dan ini merupakan gejala-gejala adanya masalah dalam keputusan pembelian. Berikut ini adalah data menurunnya jumlah pendapatan yang cukup signifikan pada bulan November dan Desember tahun 2018. Hal ini dapat dilihat dari data Jumlah pendapatan perbulan Johar Futsal Tahun 2018 di bawah ini : 
Tabel 1.2

Pendapatan Johar Futsal Karawang Tahun 2018

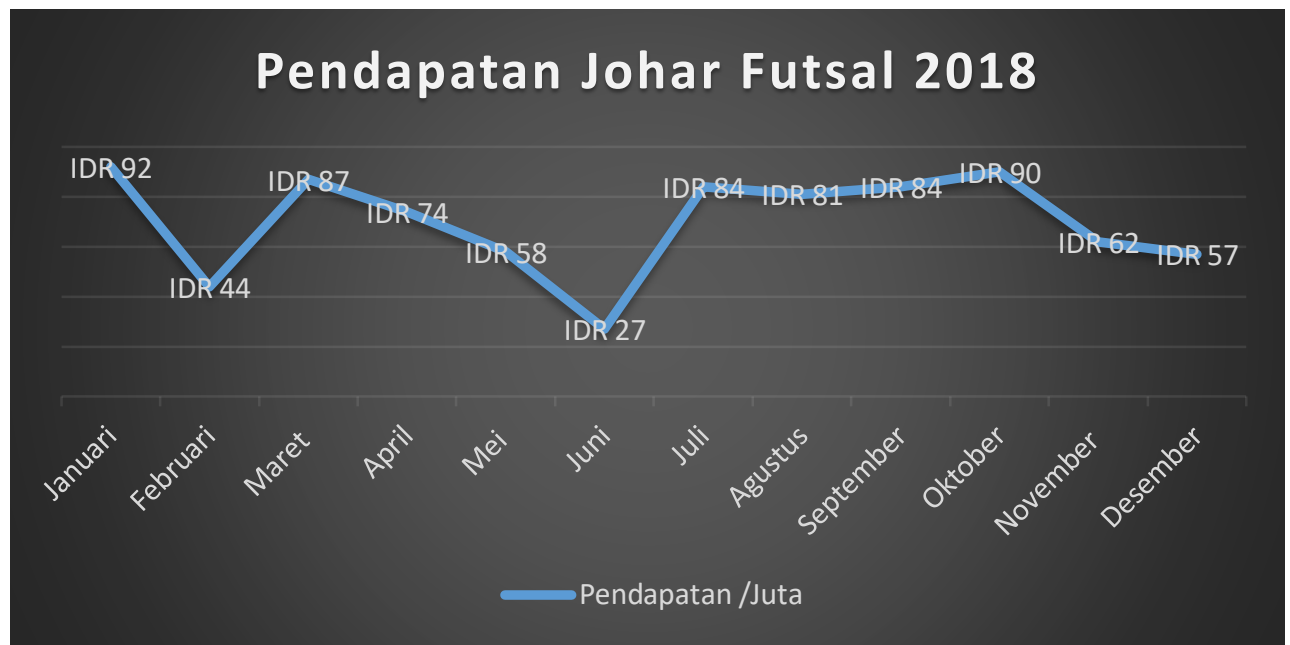

Sumber : Johar Futsal Karawang

Tabel 1.2 menunjukan jumlah pendapatan perbulan Johar Futsal Karawang dari januari sampai bulan desember tahun 2018. Kondisi di atas menunjukan terjadi sebuah fenomena naik dan turunnya pendapatan penjualan pada Johar Futsal, pada bulan november tahun 2018 pendapatan Johar Futsal mengalami penurunan menjadi Rp 62.000.000 dengan selisih jumlah pendapatan sebesar Rp 18.000.000 dari bulan oktober, kemudian pada bulan desember tahun 2018 pendapatan Johar Futsal mengalami penurunan menjadi Rp 57.000.000 dengan selisih jumlah pendapatan sebesar Rp 5.000.000 dari bulan oktober. Tingkat penjualan merupakan gambaran dari rendahnya keputusan pembelian konsumen terhadap bisnis jasa lapangan Johar Futsal Karawang.

Berdasarkan uraian di atas, maka penulis merasa tertarik untuk melakukan penelitian tentang kualitas pelayanan, lokasi dan keputusan pembelian yang dilakukan di Johar Futsal. Maka didalam penyusunan penelitian ini, penulis mengambil judul : PENGARUH KUALITAS PELAYANAN DAN LOKASI TERHADAP KEPUTUSAN PEMBELIAN PADA JOHAR FUTSAL KARAWANG. 


\section{Rumusan Masalah}

Berdasarkan dari uraian di atas, maka penulis merumuskan masalah yaitu sebagai berikut :

1. Bagaimana kualitas pelayanan Johar Futsal Karawang ?

2. Bagaimana lokasi Johar Futsal Karawang ?

3. Bagaimana keputusan pembelian Johar Futsal Karawang?

4. Seberapa besar pengaruh kualitas pelayanan dan lokasi secara parsial terhadap keputusan pembelian pada Johar Futsal Karawang?

5. Seberapa besar pengaruh kualitas pelayanan dan lokasi secara simultan terhadap keputusan pembelian pada Johar Futsal Karawang?

\section{Tujuan Penelitian}

Sesuai dengan identifikasi masalah, maka yang menjadi tujuan penelitian ini adalah untuk menyelesaikan masalah serta mengetahui dan menganalisis :

1. Kualitas pelayanan Johar Futsal Karawang.

2. Lokasi Anugerah Johar Futsal Karawang.

3. Keputusan pembelian Johar Futsal Karawang.

4. Besarnya pengaruh kualitas pelayanan dan lokasi secara parsial terhadap keputusan pembelian pada Johar Futsal Karawang.

5. Besarnya pengaruh kualitas pelayanan dan lokasi secara simultan terhadap keputusan pembelian pada Johar Futsal Karawang.

\section{TINJAUAN PUSTAKA}

\section{Kualitas Pelayanan}

Menurut Kotler dan Keller (2012: 131), mendefinisikan kualitas pelayanan adalah kemampuan perusahaan untuk memuaskan kebutuhan dan keinginan konsumen. Berdasarkan definisi ini, kualitas pelayanan ditentukan oleh kemampuan perusahaan memenuhi kebutuhan dan keinginan konsumen sesuai dengan ekspektasi konsumen. 
Pengukuran terhadap kualitas pelayanan dinyatakan dalam lima dimensi kualitas pelayanan jasa. Lima dimensi kualitas pelayanan tersebut menurut Kotler dan Keller (2012:374), adalah :

1. Bukti Fisik (Tangible)

2. Empati (Empathy)

3. Kehandalan (Reliability)

4. Daya Tanggap (Responsiveness)

5. Jaminan (Assurance)

\section{Lokasi}

Lokasi menurut Tjiptono (2015:345) Lokasi mengacu pada berbagai aktivitas pemasaran yang berusaha memperlancar dan mempermudah penyampaian atau penyaluran barang dan jasa dari produsen kepada konsumen. Secara garis besar, ada dua kemungkinan pertimbangan dalam hal lokasi fasilitas jasa. Pertama, pelanggan mendatangi lokasi fasilitas jasa dan yang kedua adalah penyedia jasa yang mendatangi pelanggan.

Indikator lokasi Menurut Fandy Tjiptono (dalam Kuswatiningsih, 2016:15) pemilihan lokasi fisik memerlukan pertimbangan cermat terhadap faktor-faktor berikut:

1. Akses, yaitu lokasi yang dilalui mudah dijangkai sarana transportasi umum.

2. Visibilitas, yaitu lokasi atau tempat yang dapat dilihat dengan jelas dari jarak pandang normal.

3. Lalu lintas, menyangkut dua pertimbangan utama, yaitu :

(1) Banyak orang yang berlalu lalang bisa memberikan peluang besar terjadinya impulse buying, yaitu keputusan pembelian yang sering terjadi spontan atau tanpa perencanaan dan

(2) Kepadatan dan kemacetan lalu lintas bisa juga menjadi hambatan.

4. Tempat parkir yang luas, nyaman dan aman.

5. Ekspansi, yaitu tersedia tempat yang cukup luas untuk perluasan usaha di kemudian hari. 
6. Lingkungan, yaitu daerah sekitar yang mendukung jasa yang ditawarkan.

7. Kompetisi, yaitu lokasi pesaing. Dalam menentukan lokasi sebuah usaha, perlu dipertimbangkan apakah di jalan atau daerah tersebut telah terdapat banyak usaha yang sejenis atau tidak.

8. Peraturan Pemerintah yang berisi ketentuan untuk mengatur lokasi dari sebuah usaha-usaha tertentu, misalnya bengkel kendaraan bermotor dilarang berlokasi yang terlalu berdekatan dengan tempat ibadah.

\section{Keputusan Pembelian}

Keputusan pembelian adalah tindakan dari konsumen untuk membeli produk baik itu berupa jasa ataupun berupa barang. Menurut Kotler dan Amstrong (2014:158) "Customer buyer behavior refers to the buying behavior of final consumersindividuals and households that buy goods and services for personal consumption".

Kegiatan pembelian merupakan suatu rangkaian tindakan fisik maupun mental yang dialami leh seorang konsumen dalam melakukan pembelian. Dalam melakukan pembelian, terdapat tahapan-tahapan yang akan menghasilkan suatu keputusan untuk membeli apun tidak membeli dan setelah melakukan pembelian konsumen merasa puas atau tidak terhadap barang atau jasa tersebut. Menurut Kotler dan Keler (2016:195) "The costumer typically passed through five stage : 44 problem recognition, information search, evaluation of alternatives, purchase decision, and postpurchase behaviour"

1. Pengenalan masalah

2. Pencarian Informasi

3. Evaluasi Alternatif

4. Keputusan Pembelian

5. Perilaku Pasca Pembelian 


\section{Paradigma Penelitian}

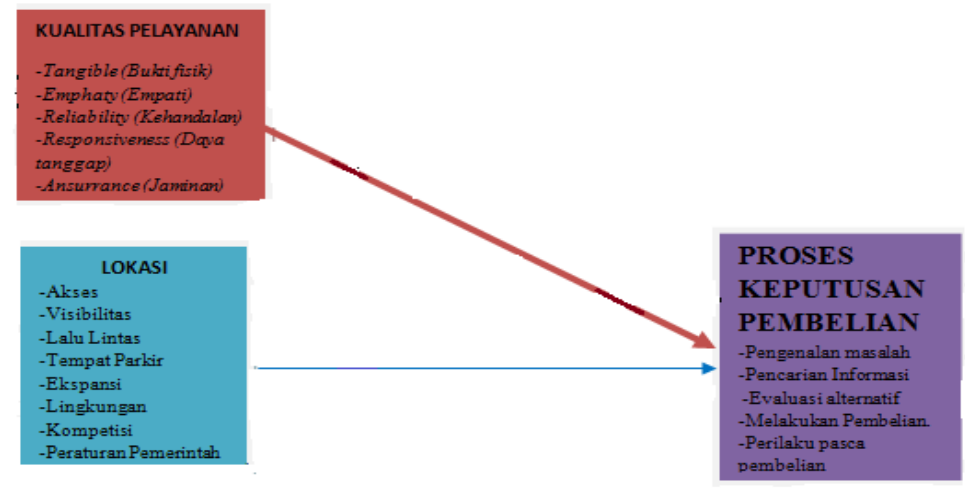

Gambar 1. Paradigma Penelitian

\section{Hipotesa Penelitian}

Dalam penelitian ini hipotesis yang diajukan adalah :

1. Terdapat pengaruh kualitas pelayanan dan lokasi secara parsial terhadap keputusan pembelian konsumen pada Johar Futsal Karawang.

2. Terdapat pengaruh kualitas pelayanan dan lokasi secara simultan terhadap keputusan pembelian konsumen Johar Futsal Karawang.

\section{METODE PENELITIAN}

\section{Jenis Penelitian}

Pada penelitian ini menggunakan metode kuantitatif dengan tujuan penelitian yang berupaya untuk memberikan generalisasi mengenai pengaruh kualitas pelayanan dan lokasi terhadap keputusan pembelian.

Secara deskriptif penelitian ini bertujuan untuk memperoleh gambaran mengenai variabel Kualitas Pelayanan, variabel Lokasi sebagai variabel bebasnya dan Keputusan Pembelian sebagai variabel terikat. Sedangkan secara verifikatif bertujuan untuk menguji hipotesis dengan perhitungan statistik.

\section{Waktu dan Tempat Penelitian}

Penelitian ini dilaksanakan pada rentang waktu bulan desember 2019 sampai dengan bulan april 2020, dan tempat penelitian di Johar Futsal Karawang. 


\section{Operasionalisasi Variabel}

Dalam penelitian ini peneliti menggunakan tiga variabel yaitu dua variabel bebas $\left(\mathrm{X}_{1}\right.$ dan $\left.\mathrm{X}_{2}\right)$ dan satu variabel terikat $(\mathrm{Y})$. Dalam hal ini variabel $\mathrm{X}_{1}$ adalah kualitas pelayanan, dan variabel $\mathrm{X}_{2}$ adalah Lokasi merupakan variabel yang mempengaruhi variabel Y yaitu Keputusan Pembelian di Johar Futsal Karawang.

\section{Sumber Dan Cara Penentuan Data/Informasi}

Jenis data yang digunakan dalam penelitian ini adalah data primer dan data sekunder.

1. Data Primer

Pengumpulan data primer dalam penelitian ini melalui cara menyebarkan kuesioner kepada konsumen yang datang ke Johar Futsal Karawang.

2. Data Sekunder

Dalam hal ini penulis mengumpulkan data secara library research, yaitu dengan melihat buku-buku (literature) yang berhubungan dengan masalah penelitian dan dapat melengkapi/mendukung data primer.

\section{Populasi Dan Sampel}

Dalam penelitian ini populasinya adalah konsumen Johar Futsal Karawang. Populasi yang diambil dari konsumen yang menggunakan lapangan futsal di Johar Futsal Karawang selama satu bulan yaitu sekitar 5.114 pengunjung.

Adapun peneliti menggunakan rumus Slovin. Rumus Slovin untuk menentukan sampel adalah :

$$
\mathrm{n}=\frac{N}{1+\mathrm{N}(e)^{2}}
$$

Keterangan :

$\mathrm{n}=$ Ukuran sampel/jumlah responden

$\mathrm{N}=$ Ukuran populasi

$\mathrm{e}=$ Persentase kelonggaran ketelitian kesalahan pengambilan sampel yang masih bisa ditolerir; $\mathrm{e}=0,05$ 
Jumlah populasi dalam penelitian ini adalah 5.114 orang, sehingga persentase kelonggaran yang digunakan adalah 10\%. Maka untuk mengetahui sampel penelitian, berikut perhitungannya :

$$
\mathrm{n}=\frac{5.114}{1+5.114(0,1)^{2}}=98,08 \text { dibulatkan } 98
$$

Jumlah sampel dibulatkan menjadi 98 orang

Berdasarkan perhitungan di atas, sampel yang menjadi responden dalam penelitian ini sebanyak 98 orang, sampel diambil berdasarkan teknik probability sampling, simple random sampling, dimana peneliti memberikan peluang yang sama bagi setiap unsur (anggota) populasi untuk dipilih menjadi anggota sampel yang dilakukan secara acak tanpa memperhatikan strata yang ada dalam populasi itu sendiri.

\section{Teknik Pengumpulan Data}

Pada penelitian ini menggunakan metode pengumpulan data sebagai berikut:

1. Penelitian Lapangan (Field Research)

Dalam penelitian lapangan tersebut penulis menggunakan beberapa prosedur yaitu
a. Angket
b. Observasi
c. Wawancara

Pada penelitian ini, penulis melakukan wawancara terhadap konsumen Johar Futsal Karawang.

2. Penelitian Kepustakaan (Library Research)

Yaitu mencari, mempelajari dan mengumpulkan teori serta bahan-bahan yang mendukung bagi penulis dengan mempelajari informasi dari beberapa literature yang berkaitan dengan masalah yang sedang diteliti penulis 


\section{Rancangan Analisis dan Uji Hipotesis}

\section{Rancangan Analisis Deskriptif}

Analisis deskriptif menggunakan skala ordinal dan rentang skala untuk menganalisis data dengan cara menggambarkan Kualitas Pelayanan, dan Lokasi terhadap Keputusan Pembelian di Johar Futsal Karawang.

Untuk menentukan skala prioritas dari setiap variabel yang diukur selanjutnya dihitung skala dari skor yang diukur dengan menggunakan analisis rentang skala.

\section{Rancangan Analisis Verifikatif}

Menurut Juliansyah Noor (2012:20), pengertian metode penelitian verifikatif adalah metode penelitian yang digunakan untuk menguji kebenaran dari sesuatu (ilmu pengetahuan) yang telah ada". Analisis verifikatif yang digunakan dalam penelitian ini menggunakan analisis analisis regresi linier berganda,

\section{Uji Hipotesis}

\section{Uji Hipotesis (Uji t)}

Untuk mengetahui besarnya pengaruh masing-masing variabel independen secara individual (parsial) terhadap variabel dependen. Hasil uji thitung ini ada pada output perangkat lunak, dapat dilihat pada tabel coefficient level of significance yang digunakan sebesar 5\% atau (a) $=0,05$. Apabila $\mathrm{t}_{\text {hitung }}>\mathrm{t}_{\text {tabel }}$ maka $\mathrm{H}_{0}$ ditolak dan $\mathrm{H}_{\mathrm{a}}$ diterima, artinya variabel independen secara parsial tidak mempunyai pengaruh yang signifikan terhadap variabel dependen. Untuk yang memakai variabel simultan harus menambahkan uji $\mathrm{F}$ dengan tujuan untuk menentukan apakah suatu dugaan hipotesis 3 variabel bebas secara bersama-sama terhadap variabel terikat tersebut sebaiknya diterima atau ditolak. Pengujian ini dilakukan untuk mengetahui signifikasi atau tidaknya pengaruh variabel bebas secara bersamasama / simultan terhadap variabel terikatnya. Apabila hasil uju $\mathrm{f}_{\text {hitung }}$ lebih dari $\mathrm{f}_{\text {tabel }}$ berarti variabel cikup signifikan untuk menjelaskan variabel terikat. 


\section{HASIL PENELITIAN DAN PEMBAHASAN}

\section{Analisis Validitas Data}

Berdasarkan hasil uji validitas pada semua variabel dengan menggunakan SPSS terlihat pada kolom corrected item-total correlation dan hasilnya tidak ada yang negatif dan lebih dari 0,3 untuk semua pernyataan.

\section{Analisis Reliabilitas Data}

Dengan menggunakan SPSS 19, hasil uji reliabilitas dari semua variabel menunjukkan sudah reliable karena nilai variabel tersebut sudah diatas 0,7 .

\section{Uji Normalitas}

Dengan menggunakan SPSS 19, hasil uji normalitas dari semua variabel menunjukan nilai signifikan $>0,05$, sehingga hasilnya menunjukkan semua variabel berdistribusi normal.

\section{Analisis Deskriptif}

\section{Kualitas Pelayanan (X1)}

Kualitas Pelayanan mencapai nilai total skor 2693 dengan nilai rata-rata skor 299,2 berada pada nilai rentang skala 254,8 - 333,2 dengan kategori cukup setuju.

\section{Lokasi (X2)}

Lokasi mencapai nilai total skor 2751 dengan nilai rata-rata skor 305,6 berada pada nilai rentang skala 254,8 - 333,2 dengan kategori cukup setuju

\section{Keputusan Pembelian (Y)}

Keputusan Pembelian mencapai nilai total skor 1399 dengan nilai rata-rata skor 279,8 berada pada nilai rentang skala 239,2 - 312,8 dengan kategori cukup setuju

\section{Pengujian Hipotesis}

Korelasi berganda antara Kualitas Pelayanan $\left(\mathbf{X}_{1}\right)$, Lokasi $\left(\mathbf{X}_{2}\right)$ dengan Keputusan Pembelian (Y)

Korelasi Kualitas Pelayanan $\left(\mathrm{X}_{1}\right)$ dan Lokasi $\left(\mathrm{X}_{2}\right)$ dengan Keputusan Pembelian (Y) mempunyai nilai koefisien korelasi berganda (r) sebesar 0,562 dan jika diinterpretasikan dengan keeratan hubungan kedua variabel ini mempunyai 
tingkat hubungan yang sedang (Sugiyono, 2014:84) dan searah karena nilainya positif

\section{Hipotesis Pengaruh Variabel Secara Parsial}

1) Hipotesis pengaruh kualitas pelayanan $\left(X_{1}\right)$ terhadap keputusan pembelian (Y) Besaran pengaruh parsial Kualitas Pelayanan $\left(\mathrm{X}_{1}\right)$ terhadap Keputusan Pembelian (Y) mempunyai nilai koefisien regresi sebesar 0,094 dan mempunyai nilai koefisien determinasi atau berpengaruh sebesar $4,12 \%$.

2) Hipotesis pengaruh lokasi $\left(\mathrm{X}_{2}\right)$ terhadap keputusan pembelian (Y) Pengaruh parsial Lokasi $\left(\mathrm{X}_{2}\right)$ terhadap Keputusan Pembelian (Y) mempunyai nilai koefisien regresi sebesar 0,489 atau mempunyai nilai koefisien determinasi atau berpengaruh sebesar $27,4 \%$.

\section{Analisis Reresi Berganda}

Berdasarkan hasil pengolahan data tersebut menunjukan bahwa nilai koefisien regresi sebesar 0,489 > 0,094, maka dinyatakan bahwa variabel lokasi $\left(\mathrm{X}_{2}\right)$ lebih besar dan lebih dominan memberikan kontribusi terhadap keputusan pembelian dibandingkan dengan variabel kualitas pelayanan $\left(\mathrm{X}_{1}\right)$.

\section{Hipotesis Pengaruh Variabel Secara Simultan}

Berdasarkan hasil penelitian ini menunjukan bahwa kualitas pelayanan dan lokasi memiliki kontribusi terhadap Keputusan pembelian (Y) sebesar 31,6\% sedangkan sisanya 0,684 atau sebesar $68,4 \%$ merupakan pengaruh kontribusi variabel lain $(\varepsilon)$ yang tidak diteliti. Variabel Kualitas Pelayanan $\left(X_{1}\right)$ berpengaruh signifikan terhadap Keputusan Pembelian (Y), dengan kriteria uji nilai Sig. $(0,03)<\alpha(0,05)$ dan t hitung $(1,791)>t$ tabel $(1,290)$. Artinya Ho ditolak. Hal ini dapat dijelaskan bahwa kualitas pelayanan mempunyai nilai signifikansi atau bermakna terhadap keputusan pembelian. Variabel Lokasi $\left(\mathrm{X}_{2}\right)$ berpengaruh signifikan terhadap Keputusan Pembelian $(Y)$, dengan kriteria uji nilai Sig. $(0,000)<\alpha(0,05)$ dan $\mathrm{t}$ hitung $(4,124)>\mathrm{t}$ tabel $(1,290)$. Artinya Ho ditolak. Hal ini menunjukan bahwa lokasi mempunyai nilai signifikansi atau bermakna terhadap keputusan pembelian. 
Kualitas Pelayanan $\left(\mathrm{X}_{1}\right)$, dan Lokasi $\left(\mathrm{X}_{2}\right)$ berpengaruh signifikan terhadap Keputusan Pembelian (Y), diperoleh nilai Sig. $0,000<\alpha(0,05)$ dan F hitung $(21,906)>\mathrm{F}$ tabel $(3,09)$.

\section{Pembahasan Deskriptif}

Adapun pembahasan dari metode deskriptif mengenai masing-masing variabel dalam penelitian ini dapat diuraikan sebagai berikut.

1. Kualitas Pelayanan mencapai nilai total skor 2693 dengan nilai rata-rata skor 299,2 berada pada nilai rentang skala 254,8 - 333,2 dengan kategori cukup setuju. Artinya konsumen memberikan respon yang cukup baik tetapi belum optimal terhadap kualitas pelayanan yang diterapkan selama ini oleh Johar Futsal Karawang.

2. Lokasi mencapai nilai total skor 2751 dengan nilai rata-rata skor 305,6 berada pada nilai rentang skala 254,8 - 333,2 dengan kategori cukup setuju. Artinya konsumen memberikan respon yang cukup baik tetapi belum optimal terhadap lokasi Johar Futsal Karawang.

3. Keputusan Pembelian mencapai nilai total skor 1399 dengan nilai ratarata skor 279,8 berada pada nilai rentang skala 239,2 - 312,8 dengan kategori cukup setuju. Artinya konsumen memberikan respon cukup baik tetapi belum optimal terhadap keputusan pembelian pada Johar Futsal Karawang

\section{Pembahasan Verifikatif}

1. Korelasi Kualitas Pelayanan (X1) dan Lokasi (X2) dengan Keputusan Pembelian (Y) mempunyai nilai koefisien korelasi berganda (r) sebesar 0,562 dan jika diinterpretasikan dengan keeratan hubungan kedua variabel ini mempunyai tingkat hubungan yang sedang (Sugiyono, 2014:84) dan searah karena nilainya positif

2. Pengaruh parsial kualitas pelayanan $\left(\mathrm{X}_{1}\right)$ dan lokasi $\left(\mathrm{X}_{2}\right)$ terhadap keputusan pembelian (Y). 
a. Pengaruh Parsial Kualitas Pelayanan $\left(\mathrm{X}_{1}\right)$ terhadap Keputusan Pembelian (Y) adalah sebesar 0,094. Hal ini menunjukkan pengaruh positif antara kualitas pelayanan $\left(\mathrm{X}_{1}\right)$ terhadap keputusan pembelian $(\mathrm{Y})$.

b. Pengaruh Parsial Lokasi $\left(\mathrm{X}_{2}\right)$ terhadap Keputusan Pembelian (Y) adalah sebesar 0,489. Hal ini menunjukkan pengaruh positif antara lokasi $\left(\mathrm{X}_{2}\right)$ terhadap keputusan pembelian (Y).

3. Variabel Kualitas Pelayanan (X1) berpengaruh signifikan terhadap Keputusan Pembelian (Y), dengan kriteria uji nilai Sig. $(0,03)<\alpha(0,05)$ dan $t$ hitung $(1,791)>t$ tabel $(1,290)$. Artinya Ho ditolak. Variabel Lokasi (X2) berpengaruh signifikan terhadap Keputusan Pembelian (Y), dengan kriteria uji nilai Sig. $(0,000)<\alpha(0,05)$ dan $t$ hitung $(4,124)>t$ tabel (1,290). Artinya Ho ditolak.

4. Kualitas Pelayanan (X1), dan Lokasi (X2) berpengaruh signifikan terhadap Keputusan Pembelian (Y), diperoleh nilai Sig. $0,000<\alpha(0,05)$ dan F hitung $(21,906)>\mathrm{F}$ tabel $(3,09)$.

\section{KESIMPULAN DAN SARAN}

\section{Kesimpulan}

Berdasarkan tujuan penelitian yang dikemukakan dan selanjutnya dibandingkan dengan hasil penelitian dan pembahasan maka dapat dibuat kesimpulan sebagai berikut:

1. Kualitas Pelayanan mencapai nilai total skor 2693 dengan nilai rata-rata skor 299,2 berada pada nilai rentang skala 254,8 - 333,2 dengan kategori cukup setuju. Artinya konsumen memberikan respon yang cukup baik tetapi belum optimal terhadap kualitas pelayanan yang diterapkan selama ini oleh Johar Futsal Karawang. Namun terdapat satu indikator yang menurut persepsi konsumen masih rendah dan nilainya terkecil yaitu indikator kebersihan toilet dengan skor 235.

2. Lokasi mencapai nilai total skor 2751 dengan nilai rata-rata skor 305,6 berada pada nilai rentang skala 254,8 - 333,2 dengan kategori cukup setuju. Artinya konsumen memberikan respon yang cukup baik tetapi 
belum optimal terhadap lokasi Johar Futsal Karawang. Namun terdapat satu indikator yang menurut persepsi konsumen masih rendah dan nilainya terkecil yaitu indikator luas tempat parkir dengan skor 264.

3. Keputusan Pembelian mencapai nilai total skor 1399 dengan nilai ratarata skor 279,8 berada pada nilai rentang skala 239,2 - 312,8 dengan kategori cukup setuju. Artinya konsumen memberikan respon cukup baik tetapi belum optimal terhadap keputusan pembelian pada Johar Futsal Karawang. Namun terdapat satu indikator yang menurut persepsi konsumen masih rendah dan nilainya terkecil yaitu indikator perilaku pasca pembelian dengan skor 252.

4. Besarnya pengaruh kualitas pelayanan dan lokasi terhadap keputusan pembelian, secara parsial memiliki kontribusi variabel kualitas pelayanan sebesar 4,12\%, sedangkan kontribusi variabel lokasi adalah sebesar $27,45 \%$, disini terungkap bahwa lokasi memiliki pengaruh yang paling besar terhadap keputusan pembelian daripada kualitas pelayanan

5. Nilai koefisien determinasi secara silmutan (R Square) sebesar 0,316. Nilai tersebut mengindikasikan bahwa kualitas pelayanan dan lokasi memiliki pengaruh terhadap proses keputusan pembelian sebesar 31,6\%, sedangkan sisanya $(100 \%-31,6 \%=68,4 \%)$ dipengaruhi oleh variabel independen lainnya.

\section{Saran}

Adapun saran-saran yang dapat dipertimbangkan sehubungan dengan hasil penelitian adalah sebagai berikut :

1. Kebersihan toilet nilainya masih rendah oleh karena itu Johar Futsal Karawang perlu memperhatikan dan meningkatkan kualitas pelayanan dalam hal kebersihan toilet ini meliputi : kebersihan toilet yang dijaga berkala secara bersama-sama, toilet dilengkapi dengan fasilitas kebersihan yang terpadu seperti dispenser sabun dan pengering tangan, aliran 
pembuangan air lancar, dinding atap harus dalam kondisi bersih dan ventilasi sudara serta cahaya yang memadai.

2. Luas tempat parkir nilainya masih rendah oleh karena itu Johar Futsal Karawang perlu memperhatikan dan meningkatkan lokasi dalam hal luas tempat parkir ini meliputi : parkir modular, yaitu parkir dengan sistem modul knock down atau lebih umumnya parkir bertingkat. sehingga persepsi lokasi dalam hal luas tempat parkir akan lebih baik dimata konsumen.

3. Perilaku pasca pembelian nilainya masih rendah oleh karena itu Johar Futsal Karawang perlu memperhatikan dan meningkatkan keputusan pembelian dalam hal perilaku pasca pembelian ini meliputi : mempertahankan dan meningkatkan semua elemen dari kualitas pelayanan dan lokasi yang sudah memiliki persepsi baik di benak konsumen, kemudian memperbaiki setiap elemen yang memiliki persersi kurang baik di benak konsumen. Kemudian Johar Futsal harus memantau kepuasan pasca pembelian, Tindakan pasca pembelian, dan perusahaan berusaha mempengaruhi pikiran konsumen dan mengubah sikap komsumen, Hal tersebut akan secara otomatis mempengaruhi perilaku pasca pembelian konsumen Johar Futsal Karawang menjadi lebih baik kedepannya.

4. Kualitas pelayanan (X1) secara umum berpengaruh terhadap keputusan pembelian namun kontribusinya lebih kecil dibandingkan dengan variabel Lokasi (X2) di Johar Futsal Karawang, sehingga perlu ditingkatkan kualitas pelayanannya dengan meningkatkan dengan selalu mengevaluasi setiap pelayanan yang diberikan kepada konsumen setiap bulannya, dan selalu memaksimalkan semua sumber daya yang dimiliki perusahaan termasuk karyawan untuk selalu memberikan pelayanan yang maksimal bagi konsumen Johar Futsal Karawang.

5. Meneliti aspek lain yang memiliki kemungkinan mempengaruhi keputusan pembelian, yang tidak dijadikan variabel dalam penelitian ini, karena berdasarkan hasil koefisien determinasi yang menunjukkan bahwa ada 
sebesar $68,4 \%$ variabel lain yang mempengaruhi keputusan pembelian, misalnya promis, citra merek dan harga.

\section{DAFTAR PUSTAKA}

Ghanimata, Fify Anita. 2012. Analisis Pengaruh Harga, Kualitas Produk dan Lokasi Terhadap Keputusan Pembelian pada Produk Bandeng Jwana Elrina Semarang. Diperoleh dari eprints.undip.ac.id

Fandy Tjiptono, Ph.D. 2015. Strategi Pemasaran, Edisi 4, Penerbit Andi, Yogyakarta

Kotler, Philip dan Gary Armstrong. 2012. Principles Of Marketing, 14th Edition, Prentice-Hall Pearson, USA.

Kotler, Philip \& Gerry Armstrong, (2014): Principle Of Marketing, 15th edition. New Jersey: Pearson Pretice Hall.

Kotler, Philip. dan Keller, K.L. 2009. Manajemen Pemasaran. Jilid I. Edisi ke 13. Erlangga. Jakarta.

Kotler, Philip. dan Keller, K.L. 2012. Marketing Management, 14th Edition, Prentice Hall Pearson, USA.

Kotler, Philip and Kevin Lane Keller, (2016): Marketing Management, 15th Edition New Jersey: Pearson Pretice Hall, Inc.

M. Rizwar Ghazali dan Hidayati Retno. 2011. Analisis Pengaruh Lokasi, Promosi dan Kualitas Layanan Terhadap Keputusan Membeli (Warnet XYZ jl.singosari Semarang). Undergraduate Thesis, Fakultas Ekonomika dan Bisnis. . Diperoleh dari eprints.undip.ac.id

Mimi SA. 2015. Pengaruh Harga, Kualitas Pelayanan, Lokasi dan Keberagaman Produk Terhadap Keputusan Pembelian Konsumen di Ranch Market. Jurnal Ekonomi/Volume XX, No. 01, Maret 2015 : 89-10

Fadhila, Risa dan Sri, Rahayu Sri Astuti .2013. Analisis Pengaruh Word of mouth, Kualitas Layanan, Kualitas Produk dan Lokasi Terhadap Keputusan Pembelian Konsumen (Studi Pada Toko Leo Fashion Karangjati Kabupaten Semarang. Undergraduate Thesis, Fakultas Ekonomika dan Bisnis. . Diperoleh dari eprints.undip.ac.id 
Sugiyono. 2012. Metode Penelitian Kuantitatif, Kualitatif dan R \& D, CV. Alfabeta, Bandung.

Sugiyono. 2013. Metode Penelitian Kuantitatif, Kualitatif dan R \& D, CV. Alfabeta, Bandung.

Sugiyono. 2014. Metode Penelitian Pendidikan Pendekatan Kuantitatif, Kualitatif dan R \& D, CV. Alfabeta, Bandung. 
